17-21 January, CIMO Working Group on Upper-Air Technology Basic to User Needs, Geneva (World Weather Watch Department, World Meteorological Office, Geneva, Switzerland).

25 January, Radiological Protection Future Research Requirements, London (Prof. J.H. Martin, Dept of Medical Biophysics, Blackness Laboratory, University of Dundee, Dundee, UK).

7-11 February, Water Hyacinth, Hyderbad (Dr G. Thyagerajan, Regional Research Laboratory, Hyderabad 500 009, India).

13-18 February, Recent Advances in Bone Marrow Transplantation, Utah (UCLA Symposia, Molecular Biology Institute, University of California, Los Angeles, California 90024, USA).

16 February, New Radiopharmaceuticals and their Clinical Applications, London (The British Institute of Radiology, Institute House, 36 Portland Place, London W1, UK).

21-23 February, Diet and Nutrition, Tel Aviv (The Secretariat, International Conference on Diet and Nutrition, PO Box 29784, Tel Aviv, 61297, Israel).

21-25 February, Cooperative Education, Melbourne (The Chairman, World Conference on Cooperative Education, PO Box 218, Hawthorn, Victoria 3122, Australia).
1-4 March, Space Physiology, Toulouse (CNES, Department des Affaires Universitaires, 18 Ave Edouard-Belin, 31055 Toulouse Cedex, France).

21 February -4 March, Commission for Agricultural Meteorology, Geneva (World Climate Programme Department, World Meteorological Organization, Geneva, Switzerland).

7-12 March, Analytical Chemistry and Applied Spectroscopy, Atlantic City (Pittsburgh Conference, 437 Donald Rd, Pittsburgh, Pennsylvania 15235, USA).

8-11 March, Nickel in the Human Environment, Lyon (Dr W. Davis, IARC, 150 cours Albert Thomas, 69372 Lyon Cedex 08, France).

9 March, Digital Radiography, London (The British Institute of Radiology, Institute House, 36 Portland Place, London W1, UK).

13-17 March, Microlithography, California (SPIE, PO Box 10, Bellingham, Washington 98227-0010, USA).

14-16 March, Biomedical Research, Heidelberg (Charles River Foundation, PO Box 430, Wilmington, Massachusetts 01887, USA).

14-17 March, Microbiological Quality Assurance in Industry, Brighton (Scientific Symposia Ltd, 33-35 Bowling Green Lane, London EC1, UK).
14-17 March, Poliomyelitis Control, Washington DC (Dr E.C. Chamberlayne, Fogarty International Center, Building 16A Room 205, National Institutes of Health, Bethesda, Maryland 20205, USA). 14-18 March, Reactions and Intermediates in Nitrogen Fixation Processes, Brighton (EUCHEM Conference, ARC Unit of Nitrogen Fixation, University of Sussex, Brighton, UK).

14-18 March, Informal Coordination Meeting on the Use of INMARSAT, Geneva (World Weather Watch Department, World Meteorological Organization, Geneva, Switzerland).

27-30 March, 1st European Symposium on Radiopharmacy and Radiopharmaceuticals, Elsnore (Isotope Pharmacy, Frederikssundsvej 378, DK 2700 Copenhagen/Bronsho, Denmark).

21-25 March, Annual American Society for Neurochemistry Meeting, Honolulu (Dr G.R. Dutton, College of Medicine, University of Iowa, Iowa 52242, USA).

25-28 March, British Society for Cell

Biology, Liverpool (Local Meeting Secretary, Dept of Medical Cell Biology, Liverpool University, UK).

26 March-1st April, Gene Expression, Park City (UCLA Symposia, Molecular Biology Institute, University of California, Los Angeles, California 90024, USA).

\section{New ventures}

The Arab Bureau of Education for the Gulf States has started publishing a new journal, entitled The Arab Gulf Journal of Scientific Research which will be devoted to research in basic and applied sciences. All communications should be directed to: Managing Editor, Arab Bureau of Education for the Gulf States, PO Box 3908, Riyadh, Saudi Arabia.

During the 18th General Assembly of the International Astronomical Union, a new IAU commission with the title: 'Commission 51 - Search for Extraterrestrial Life' was approved. The objectives will include: the search for planets around other stars; the search for radio transmissions, intentional or unintentional, of extraterrestrial origin; the search for biologically relevant interstellar molecules and the study of their formation processes; detection methods for potential spectroscopic evidence of biological activity; and finally the coordination of efforts in all these areas at the international level. Prof. Michael D. Papagiannis was elected President of the new commission and all IAU members who would like to join the new commission are requested to write to him at the Dept of Astronomy, Boston University, Boston, Massachusetts 02215, USA.
Following the First International Symposium on Radiation Physics, ISRP-1 (Calcutta 1974), interest has been expressed in forming an International Radiation Physics Society (IRPS) which could serve as the primary sponsor for further symposia in this interdisciplinary subject area. A protem committee has now been elected to explore and to take the necessary actions to form such a society. The primary objective of which society would be the global exchange and integration of scientific information pertaining to radiation physics, with emphasis on (1) research, theoretical and experimental, in the field of radiation physics, (2) investigations of the physical aspects of the interactions of radiation with living systems, (3) education in radiation physics and (4) utilization of radiation for peaceful purposes. Further information from Prof. D.F. Jackson, University of Surrey, Guildford, UK.

A new scientific society, the American Society for Virology, has been of ficially inauguarated with the first of what will be annual meetings. W.K. Joklik of Duke University, was elected president of the society. The major purpose of the society will be the organization of annual meetings; the 1983 meeting being scheduled for Michigan State University next summer.
The International Society of Cryptozoology aims to be a focal point for the investigation, analysis, publication, and discussion of all matters related to animals of unexpected form or size, or unexpected occurrence in time or space. The society will promote the scientific examination of all evidence related to these matters. Although the society is primarily intended for biological scientists, membership is open to all interested persons. The society will publish both a quarterly newsletter and a scholarly, refereed journal, entitled Cryptozoology, which will appear once a year. Further information can be obtained from J. Richard Greenwell, International Society of Cryptozoology, PO Box 43070, Tucson, Arizona 85733, USA.

The Agricultural Research Council is to establish an Animal Breeding Liaison Group within the Edinburgh School of Agriculture, under the leadership of Prof. J.W.B. King. Its role will be to identify problems of current concern within the animal breeding industry and to promote the rapid uptake of research into farming practice. The group will liaise closely with other research establishments and relevant industrial organizations. Further information from M.L.S. Delaney, Agricultural Research Council, 160 Great Portland St, London W1, UK. 